\title{
Temperature explains settlement patterns of the introduced bryozoan Membranipora membranacea in Nova Scotia, Canada
}

\author{
Megan Saunders*, Anna Metaxas \\ Department of Oceanography, Dalhousie University, Halifax, Nova Scotia B3H 4J1, Canada
}

\begin{abstract}
Settlement is a critical life-history stage for benthic invertebrates with a planktonic larval form, and is important for understanding mechanisms of larval supply and population dynamics. We examined spatial (metre to kilometre scales) and temporal (weekly to yearly scales) patterns in abundance of settlers of the introduced bryozoan Membranipora membranacea on the numerically dominant kelp Saccharina longicruris, at 2 sites in St. Margarets Bay, Nova Scotia, Canada. Relationships between patterns in settlement and indices of the temperature regime, such as average weekly temperature, temperature fluctuations, water column stratification and thermal history (growing degree-day) were determined using multiple linear regressions. Although settler abundance varied interannually, it was highest in early autumn, and was generally higher at depth (12 and $8 \mathrm{~m})$ than in the shallows $(4 \mathrm{~m})$. Abundance was an order of magnitude greater after a significantly warmer winter. Growing degree-day accounted for up to $81 \%$ of the variability in settler abundance, whereas average temperature, temperature fluctuations and stratification were less important. The strong positive relationship between thermal history and settlement of this ecologically important species suggests that abundance of established introduced marine species may increase with the increased temperatures predicted to result from climate change.
\end{abstract}

KEY WORDS: Larval settlement · Temperature · Thermal history · Stratification • Bathymetric patterns $\cdot$ Benthic invertebrates $\cdot$ Introduced species $\cdot$ Climate change

\section{INTRODUCTION}

The importance of larval supply in regulating populations of meroplanktonic benthic invertebrates is widely acknowledged for many species (e.g. Caley et al. 1996). Consequently, settlement, defined here as the movement of larvae from the plankton to the benthos and subsequent metamorphosis, is one of the key processes in the life history of benthic invertebrates. Moreover, an analysis of settlement patterns can lend insight into the mechanisms of larval transport to the adult benthic habitat, a process that is extremely challenging to measure in the water column (Pineda 2000).

Species with a dispersive larval phase have a great probability of being introduced to non-native ecosystems because of their ability to be transported in ballast water (Carlton 1989). Moreover, species with a rapid means of dispersal (for example a larval phase) are considered more likely to be successful invaders (Ricciardi \& Rasmussen 1998). However, observed range expansion via larval dispersal is often less than would be predicted solely by physical circulation models (Grosholz 1996). For example, in Australia, the yearly range expansion of the European green crab Carcinus maenas is only a few kilometres per year, despite a long (up to $50 \mathrm{~d}$ ) planktonic period (Thresher et al. 2003). Clearly, the processes that regulate dispersal, settlement and recruitment into the adult population can affect the success of non-native species in their new environments.

The encrusting epiphytic colonial bryozoan Membranipora membranacea has recently been introduced 
to the kelp beds of the rocky subtidal in Nova Scotia, Canada. It was first observed in Atlantic North America, off New Hampshire and southern Maine, in 1987, where it became the dominant epiphyte on kelps within 2 yr (Berman et al. 1992). It was first observed in Nova Scotia, in Mahone Bay and St. Margarets Bay, in 1992 (Scheibling et al. 1999). Genetic studies indicate that Atlantic North American populations are closely related to those in Europe (Schwaninger 1999), and they were probably introduced from that source in ballast water.

The planktotrophic larvae of Membranipora membranacea (cyphonautes) remain in the water column for approximately $4 \mathrm{wk}$ (Yoshioka 1973). They settle preferentially on the proximal (meristematic) ends of laminarian algae (Seed \& O'Connor 1981), where they metamorphose into a feeding stage, and then asexually bud new zooids to form a colony. The presence of M. membranacea colonies can have pronounced negative effects on the growth and survival of its algal substrates. Heavy encrustations of the bryozoan increase the brittleness of kelp blades (Dixon et al. 1981), leading to defoliation during periods of intense wave action (Lambert et al. 1992, Scheibling et al. 1999).

The population dynamics of Membranipora membranacea in Nova Scotia, or elsewhere along the eastern coast of North America, are poorly understood. In the Gulf of Maine, colonies grow and reproduce in summer and senesce in autumn (Ellison \& Harvell 1989). In Nova Scotia, outbreaks of $M$. membranacea occur in autumn, particularly during years with warmer than average sea surface temperature (R. E. Scheibling unpubl. data). The resultant defoliation (Scheibling et al. 1999) has facilitated the establishment of the introduced green alga Codium fragile ssp. tomentosoides (Chapman et al. 2002, Levin et al. 2002). This shift in ecosystem structure may potentially have pronounced implications for commercial fisheries of sea urchins and lobster, which rely on kelp beds for food and habitat (Chapman et al. 2002). The role of warmer water in effecting earlier or greater settlement, more successful recruitment, or faster colony growth of M. membranacea is unknown. In fact, no detailed observations exist on the spatial and temporal patterns in larval settlement of $M$. membranacea in Nova Scotia, or elsewhere along the Atlantic coast of North America. Such measures of larval supply can provide information on the factors responsible for initiation of outbreaks of harmful species, such as M. membranacea.

In Nova Scotia, water temperatures may fall below $0^{\circ} \mathrm{C}$ in winter, and can be periodically as high as $20^{\circ} \mathrm{C}$ in summer. Temperature has a direct effect on the metabolic rate of ectothermic organisms, with warmer temperatures generally associated with shorter devel- opment times and increased growth rates (Atkinson 1994). Importantly, both the current temperature and the thermal history experienced by ectothermic organisms in the past will regulate many life-history characteristics, such as growth, development and reproduction (Trudgill et al. 2005). Across depths, temperature may be homogeneous (well-mixed) or heterogeneous (stratified), and these conditions may have profound implications for distributions of larvae. For example, larvae may vary in abundance across a thermocline, or be restricted to a particular water layer. Temporal fluctuations in temperature can signal changing water masses during oceanographic processes, such as tidal movements, or upwelling and downwelling. In California, associations between temperature and upwelling processes, and abundance and transport of Membranipora membranacea larvae have been suggested (Yoshioka 1982).

The present study had 3 objectives: (1) to document spatial (metre to kilometre scales) and temporal (weekly to yearly scales) patterns in abundance of settlers of the introduced bryozoan Membranipora membranacea on the numerically dominant kelp Saccharina longicruris (formerly Laminaria longicruris, Lane et al. 2006) in Nova Scotia; (2) to examine relationships between patterns in settlement and indices of the temperature regime, including average weekly temperature, temperature fluctuations, water column stratification and thermal history (growing degreeday); and (3) to examine the effect of winter temperature on abundance of settlers. Determining the effect of temperature regime on settlement of $M$. membranacea will improve our understanding of its population dynamics, facilitate comparison of native and introduced populations, and enable prediction of climate change effects on this introduced species.

\section{MATERIALS AND METHODS}

Study area. We sampled 2 sites on the southern shore of Nova Scotia, Canada (Fig. 1), which have a granitic substratum with extensive kelp beds. The Lodge ( $\left.44^{\circ} 33^{\prime} 3^{\prime \prime} \mathrm{N}, 64^{\circ} 01^{\prime} 9^{\prime \prime} \mathrm{W}\right)$ is located on the eastern shore of St. Margarets Bay and faces east-northeast. The substratum is dominated by large boulders and cobbles, with granite outcroppings, and the bottom slope is moderately steep. At depths $<8 \mathrm{~m}$, the kelp bed is largely dominated by Saccharina longicruris, whereas between 8 and $14 \mathrm{~m}$ it consists of mixed stands of $S$. longicruris and Agarum clathratum. Paddy's Head $\left(44^{\circ} 31^{\prime} 6^{\prime \prime} \mathrm{N}, 63^{\circ} 57^{\prime} 2^{\prime \prime} \mathrm{W}\right)$ is located on the western shore near the mouth of St. Margarets Bay, and faces northwest. We sampled at the site's outer wall, where the substratum is granite bedrock that 
slopes steeply towards a sandy bottom at $\sim 18 \mathrm{~m}$ depth. At depths $<8 \mathrm{~m}$, the kelp bed consists mostly of $S$. longicruris with fewer Laminaria digitata, and between 8 and $18 \mathrm{~m}$ it is dominated by A. clathratum, with fewer $S$. longicruris and L. digitata. At each site, permanent markers were affixed to the substratum at 4, 8 and $12 \mathrm{~m}$ depths relative to Chart Datum along a transect perpendicular to shore.

Because of a well-established pattern in kelp morphology with wave exposure (Gerard \& Mann 1979), we used it to infer relative water motion between sites. In high wave exposure regions, the blades of Saccharina longicruris are long, narrow, thick and strap-like, with fluted edges. In contrast, when growing in lowenergy environments, blades are wider and thinner, and have extensively crenulated edges. Based upon observations of kelp morphologies and supported by observations of the aspect and exposure of the shorelines to the direction of predominant swells (SW), we determined that both sites are moderately exposed, but that Lodge is considerably more sheltered than Paddy's Head.

The mean current direction along the coast of Nova Scotia is from the northeast towards the southwest, and the mean circulation in St. Margarets Bay is counterclockwise (Heath 1973). Mean flushing time through the bay is approximately 5 to $10 \mathrm{~d}$ in the upper 5 to $10 \mathrm{~m}$, and 10 to $30 \mathrm{~d}$ in the deeper layer. In summer, the water column is strongly stratified throughout the bay, and large fluctuations in temperature attributed to wind-driven coastal upwelling are observed in late summer and early autumn (Heath 1973, Petrie et al. 1987). The tides in the region are semidiurnal, with a mean range of $1.49 \mathrm{~m}$ and a maximum range of $2.04 \mathrm{~m}$ (Canadian Tide and Current Tables 1988).

Temperature measurements. HOBO Pendant Data Loggers (Onset Computer Corporation) (accuracy \pm $0.47^{\circ} \mathrm{C}$ ) were used to measure temperature at $10 \mathrm{~min}$ intervals throughout the study period, from 1 July 2005 to 14 September 2006. The loggers were affixed to the permanent site markers near the benthos at 4, 8 and $12 \mathrm{~m}$ depths, at both sites. To extend the length of the temperature time series, temperature measures collected at $30 \mathrm{~min}$ intervals using Onset $\mathrm{HOBO}$ StowAway TidbiT loggers (accuracy $\pm 0.2^{\circ} \mathrm{C}$ ), from 1 January 2005 to 1 July 2005, at $8 \mathrm{~m}$ depth at Birchy Head, were also included in the analyses. Birchy Head is located $\sim 2 \mathrm{~km}$ from Lodge towards the head of the bay, along the adjacent shore (Fig. 1), with similar substratum and bottom cover of algae. Wave exposure, currents and proximity to freshwater sources, and therefore mixing processes, are more similar between the 2 above-mentioned sites than compared to Paddy's Head. Temperature data are presented as daily averages.

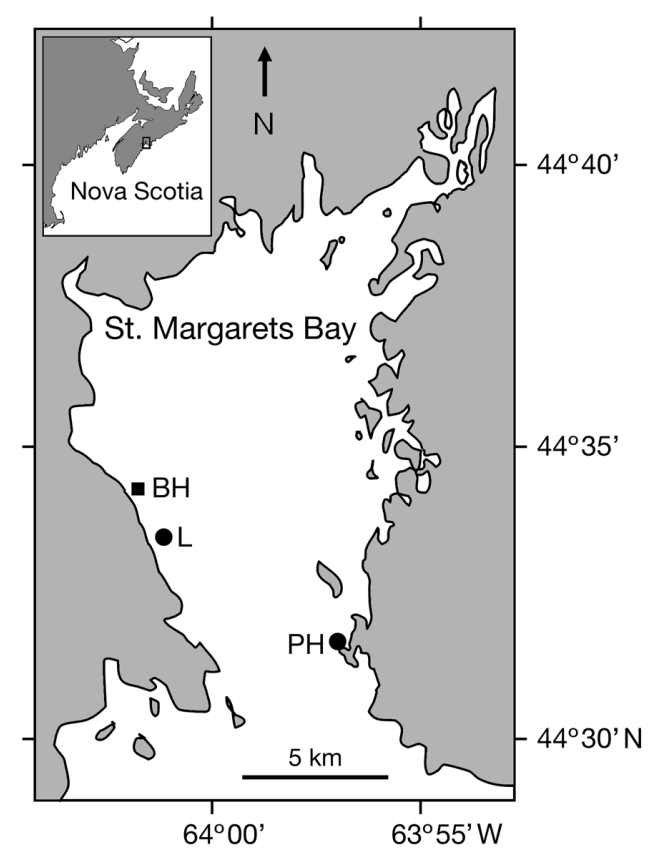

Fig. 1. Study area on the southern shore of Nova Scotia, Canada, indicating the 2 sampling sites $(\bullet)$, Lodge (L) and Paddy's Head $(\mathrm{PH})$. Additional data were obtained from Birchy Head $(\mathrm{BH}, \mathbf{\square})$, to extend the length of the temperature time series

Temperature indices. For ectothermic organisms, physiological time is often tightly coupled to thermal history (Trudgill et al. 2005). Integrated indices of thermal history (e.g. growing degree-day, GDD) have been successfully used to explain variability in many biological processes, including timing of egg hatch, germination of crops and weeds, and development of insect species (Trudgill et al. 2005). GDD is calculated by sequentially adding daily average temperatures that are above a threshold temperature for the biological process of interest. Because the threshold temperature for growth and reproduction of Membranipora membranacea in Nova Scotia is unknown, we set the threshold value to $-1.8^{\circ} \mathrm{C}$, the freezing point of seawater. GDD was calculated by (1) standardising daily average temperature to positive values by adding $1.8^{\circ} \mathrm{C}$ to each daily temperature, and (2) sequentially adding standardised daily temperature, starting at the beginning of January. This starting date was selected because temperatures between the 2 years sampled were similar until mid-January, when they began to diverge. By calculating GDD from January onwards, we accounted for all of the interannual difference in winter temperature. Moreover, in Nova Scotia, the coldest months are January, February and March, and thus January can generally be considered the onset of the thermal season. 
To further describe the temperature regime during the settlement of Membranipora membranacea, indices of weekly temperature $(T)$, stratification $(\Delta T)$ and temperature fluctuations $\left(T^{\prime}\right)$ were calculated. Based upon laboratory growth rates of new settlers (M. Saunders unpubl. data), at the temperatures during the sampling period $\left(10.9 \pm 3.4^{\circ} \mathrm{C}\right.$, mean $\left.\pm \mathrm{SD}\right)$, on any 1 sampling date, settlers could have been present on kelp for $7 \pm 3 \mathrm{~d}$ (range: 0 to $15 \mathrm{~d}$ ). Thus, to best describe temperature regime during settlement, the temperature indices were integrated over the week prior to sampling settlers. Consequently, our analysis is specific to time lags of up to $1 \mathrm{wk}$. T was calculated by averaging daily temperature over the week prior to sampling settlers, for each date, at each depth, at each site. $\Delta T$, an index of stratification in the top $12 \mathrm{~m}$ of the water column, was calculated by subtracting the mean daily temperature at $12 \mathrm{~m}$ from the mean daily temperature at $4 \mathrm{~m}$, and then averaging the daily differences over the week prior to sampling settlers, for each date, at each site. $T^{\prime}$ were obtained by calculating the absolute change in temperature between consecutive days, and averaging the daily changes over the week prior to sampling settlers, for each date, at each depth, at each site.

Sample collection. Blades of Saccharina longicruris were sampled approximately weekly from 1 July to 4 August 2005 and in September 2005, and approximately monthly from October 2005 through September 2006. On each sampling date, 7 to 15 blades were haphazardly collected from each depth, at each site. Since settlers are microscopic and clear in colour, during collection using SCUBA no investigator bias was introduced. The length of kelp blades ranged from 35 to $362 \mathrm{~cm}(108 \pm 37 \mathrm{~cm}$, mean $\pm \mathrm{SD}, \mathrm{n}=993)$, and the width ranged from 10 to $49 \mathrm{~cm}(23 \pm 7 \mathrm{~cm})$. On most occasions, we sampled both sites on the same date. If this was not possible because of time and/or weather limitations, the second site was sampled within 1 to $8 \mathrm{~d}$ of the first. Kelps were collected in mesh bags and transported in plastic tubs without seawater to the laboratory, where they were placed in aquaria with running ambient seawater in Dalhousie University's Aquatron facility. The total length of time out of water was 3 to $6 \mathrm{~h}$. Plants were held in aquaria until processing was completed ( 1 to $8 \mathrm{~d}$ ). New settlers did not grow while in aquaria (M. Saunders unpubl. data), indicating that the length of time in aquaria prior to processing did not affect results.

Quantification of settlers. The number and size of settlers of Membranipora membranacea were counted on each kelp blade using $15 \times$ magnification and LED lighting. Settlers were defined as any colony with $<2$ zooid rows (up to and including ancestrula with 1 incompletely formed zooid, generally 0.5 to $0.9 \mathrm{~mm}$ diameter). From laboratory growth experiments (M. Saunders unpubl. data), we estimated these to be 0 to $3 \mathrm{~d}$ old at $14^{\circ} \mathrm{C}, 0$ to 5 d old at $10^{\circ} \mathrm{C}$ and 0 to $15 \mathrm{~d}$ old at $6^{\circ} \mathrm{C}$.

When the number of settlers on each plant increased markedly in September 2005, and for the remainder of the study period, we subsampled 1 randomly chosen quarter of the kelp blade. In September 2006, we subsampled settlers within twelve $25 \mathrm{~cm}^{2}$ square sections of each blade. The blade was subdivided into 6 equidistantly spaced strata along its length. At each stratum, 2 square sections were haphazardly selected, 1 from the edge and 1 from the centre of the blade. For all sampling dates, the number of settlers on each blade was divided by the surface area of the blade to obtain the number of settlers $\mathrm{m}^{-2}$ kelp.

To obtain surface area of the kelp blade, the length and width of each blade were recorded, and 1 side of the blade was photographed against a white background using an HP Photosmart 435 3.1MP digital camera. The surface area of the kelp was measured using SPSS Sigma Scan Pro Image Analysis 5.0. Since the blades of Saccharina longicruris are extensively crenulated, the ratio of photographed surface area to flattened surface area was measured for 9 kelps from each depth, at each site, in November 2005. Each intact kelp blade was photographed, and then cut into small (25 to $100 \mathrm{~cm}^{2}$ ) flat pieces, and the flattened pieces were then photographed. The images were digitally analysed, and the surface areas of the flattened kelps were divided by the intact surface areas. The average ratio of surface area for flat to intact blades (crenulations) was calculated for each location, and this relationship was used to correct kelp surface area for all other sampling dates.

Statistical analyses. For the periods of maximum settlement (29 September 2005 to 19 October 2005, and 2 August 2006 to 14 September 2006) differences in abundance of settlers between sites (fixed factor, 2 levels) and among depths (fixed factor, 3 levels) were examined using 2-way ANOVA. Site was a fixed factor because the 2 sites were selected specifically for their bathymetry (substrata that slope relatively steeply) and locations (opposite sides near the mouth of St. Margarets Bay). When sites were not sampled on the same date (e.g. Lodge on 20 October 2005 and Paddy's Head on 22 October 2005; Table 1) the 2 closest dates were used. Significant differences between means were examined with Tukey's HSD post hoc tests. The data were $\log (x+1)$-transformed to remove heterogeneity of variance as detected by Levene's test. The transformations were successful except for September 2006 ( $\alpha=0.05$ ), when the lowest mean (Paddy's Head, $4 \mathrm{~m}$ ) had much higher variance compared to the other depth-by-site combinations.

Relationships between abundance of settlers and indices of the temperature regime preceding settle- 
Table 1. Dates included in 1-way ANOVA examining spatial effects (depth and site) on the abundance of Membranipora membranacea settlers at depths of 4, 8 and $12 \mathrm{~m}$. Numbers of Laminaria longicruris blades that were collected from each depth, at each site, on each date are indicated (n). L: Lodge; PH: Paddy's Head

\begin{tabular}{|lcll|}
\hline Date & Site & Date sampled & \multicolumn{1}{c|}{$\mathrm{n}$} \\
& & & $(4,8,12 \mathrm{~m})$ \\
\hline Sep 2005 & PH & 29 Sep 2005 & $9,10,10$ \\
& L & 1 Oct 2005 & $9,8,7$ \\
Oct 2005 & L & 19 Oct 2005 & $10,10,10$ \\
& PH & 19 Oct 2005 & $10,9,9$ \\
Aug 2006 & L & 2 Aug 2006 & $10,9,10$ \\
& PH & 2 Aug 2006 & $10,10,10$ \\
Sep 2006 & L & 9 Sep 2006 & $8,8,8$ \\
& PH & 14 Sep 2006 & $8,8,8$ \\
\hline
\end{tabular}

ment were explored using stepwise multiple linear regressions. The relationships between abundance of settlers and GDD, $T, \Delta T$ and $T^{\prime}$ were examined (1) for all data pooled across sites and depths, (2) for each depth pooled across sites and (3) for each site pooled across depths. We did not examine relationships for specific depths within sites as our aim was to identify the broadest scale on which statistically significant relationships between abundance of settlers and temperature regime could be generated and patterns generalised. We only used data during periods of increasing abundance of settlers (summer and early autumn).

The independent effect of GDD on abundance of settlers $[\log (x+1)$-transformed] was examined using linear regression, for data from both years combined, and for each year (2005 and 2006) separately. Analysis of covariance (ANCOVA) was used to examine the difference in magnitude of slopes between years (fixed factor, 2 levels) with GDD as a covariate. Year was treated as a fixed factor because of thermal history, as Year 1 was colder than Year 2.

For all regression analyses, settler data were log $(x+1)$-transformed to meet assumptions of normality (Shapiro-Wilk test), homogeneity of variances (examination of predicted vs. residual values) and, for the multiple regressions, multicollinearity (examination of tolerance and variance inflation values). The data met assumptions of independence (Durbin-Watson test). All tests were considered significant at $\alpha=0.05$.

\section{RESULTS}

\section{Temperature patterns}

Bathymetric patterns in temperature were strongly seasonal, with the most pronounced changes occurring at $4 \mathrm{~m}$ (Fig. 2). During the sampling period, the water was warmest in early September $2005\left(19.3^{\circ} \mathrm{C}\right.$ at Lodge, $4 \mathrm{~m}$, and $18.0^{\circ} \mathrm{C}$ at Paddy's Head, $4 \mathrm{~m}$ ) and coldest in late February and early March $2006\left(1.2^{\circ} \mathrm{C}\right.$ at $4 \mathrm{~m}$ at both sites). Interannual differences were compared at $8 \mathrm{~m}$, using the combined data sets from Birchy Head (1 January to 30 June 2005) and Lodge (1 July to 31 August 2005) for 2005, and the data set from Lodge (1 January 2006 to 31 August 2006) for 2006 (Fig. 3A). The minimum daily average winter temperature was colder in 2005 than in $2006\left(-0.69^{\circ} \mathrm{C}\right.$ on 26 February 2005, $1.43^{\circ} \mathrm{C}$ on 4 March 2006; Fig. 3A). Moreover, the average winter water temperature (January, February and March) was significantly warmer in 2006 than in $2005\left(2.71 \pm 0.56\right.$ and $1.21 \pm 1.34^{\circ} \mathrm{C}$, respectively; mean $\pm \mathrm{SD}, \mathrm{n}=90,1$-tailed $t$-test, $\mathrm{p}<0.0001$ ). Because of the warmer winter temperatures in 2006, GDD in the spring (April to June) was advanced by 4 to $5 \mathrm{wk}$ compared to 2005 (Fig. 3B).

The water column was strongly stratified from July to mid-September 2005 and from mid-May until

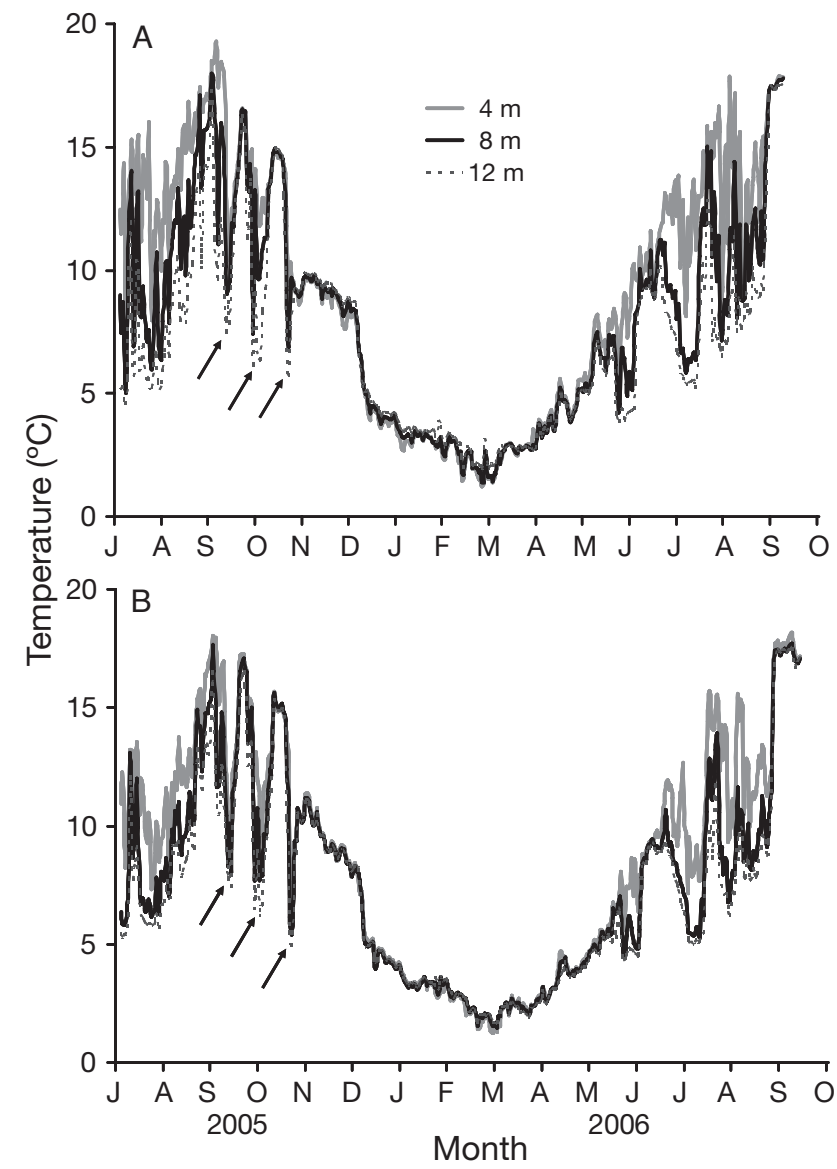

Fig. 2. Mean daily temperature $\left({ }^{\circ} \mathrm{C}\right)$ at 3 depths, at (A) Lodge and (B) Paddy's Head within St. Margarets Bay, Nova Scotia, Canada, measured over 15 mo in 2005 and 2006. Three upwelling events in September and October 2005 are indicated with arrows 

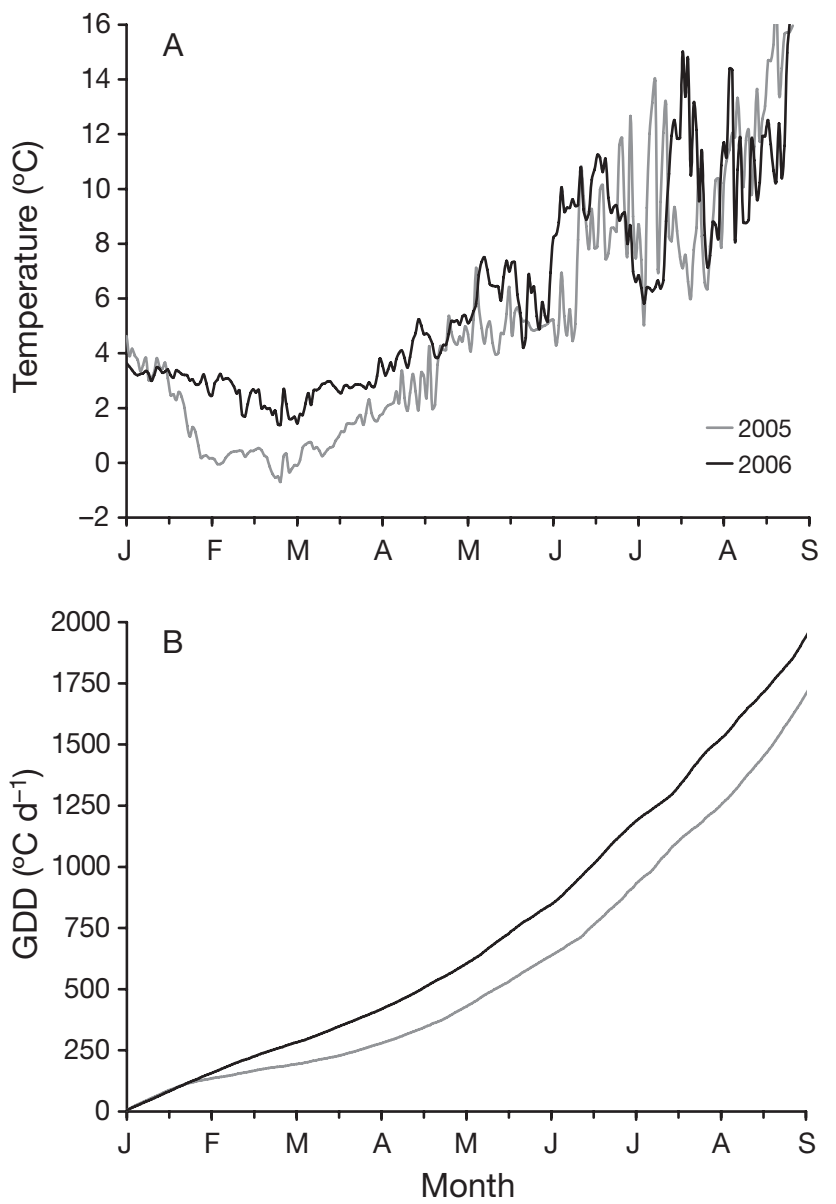

Fig. 3. Interannual differences in the winter temperature regime, measured at $8 \mathrm{~m}$ depth at Birchy Head (1 January to 30 June 2005) and Lodge (1 July to 31 August 2005, 1 January to 31 August 2006) presented as (A) daily temperature and

(B) growing degree-day (GDD)

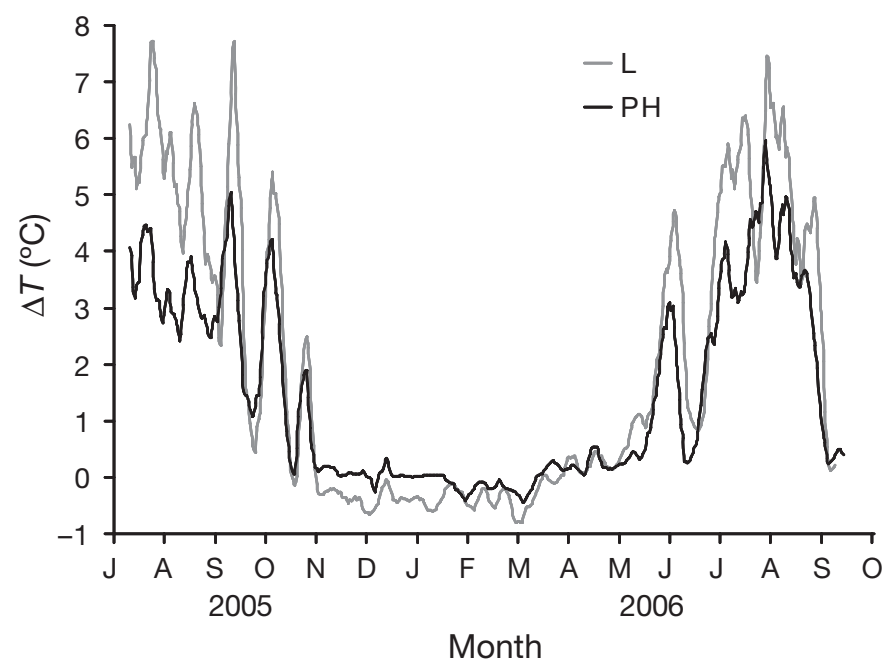

Fig. 4. Daily stratification $(\Delta T)$ at each of 2 sites (Lodge [L], Paddy's Head [PH]) within St. Margarets Bay, Nova Scotia, measured over 15 mo in 2005 and 2006

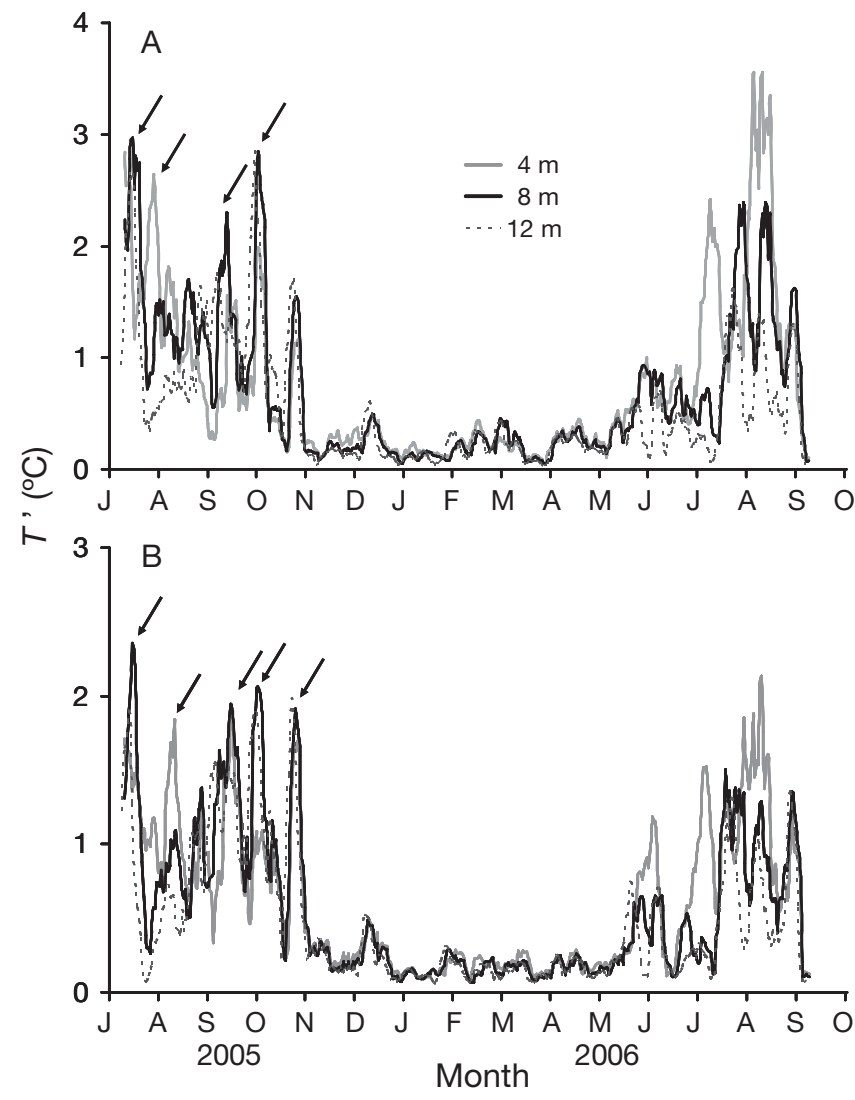

Fig. 5. Daily temperature fluctuations $\left(T^{\prime}\right)$ at 3 depths, at (A) Lodge and (B) Paddy's Head within St. Margarets Bay, Nova Scotia, measured over 15 mo in 2005 and 2006. Large fluctuations in temperature in July, August, September and October 2005 are indicated with arrows

August 2006. Maximum values of $\Delta T$ of $8^{\circ} \mathrm{C}$ (Lodge) and $6^{\circ} \mathrm{C}$ (Paddy's Head) were observed in July and September 2005, and in July 2006, respectively (Figs. 2 \& 4). Stratification periodically broke down due to upwelling in September and October 2005 (Fig. 2), and the water column was well mixed from the end of October 2005 to mid-May 2006 (Figs. 2 \& 4)

Large fluctuations in temperature were observed during periods of stratification in July to October 2005 and May to August 2006 (Figs. 2 \& 5). At both sites, 3 pronounced decreases in water temperature were observed in September and October 2005 (Fig. 2). These decreases in temperature occurred throughout the water column, and were consistent with winddriven upwelling, as has been described for this region (Heath 1973, Petrie et al. 1987). Seasonal and bathymetric patterns in temperature fluctuations were similar between sites (Figs. 2 \& 5), and cross-correlation of the temperature time series from $12 \mathrm{~m}$ at the 2 sites demonstrated that pronounced changes in temperature at Lodge lagged behind those at Paddy's Head by 8 to $24 \mathrm{~h}$. This is probably because Lodge is located 


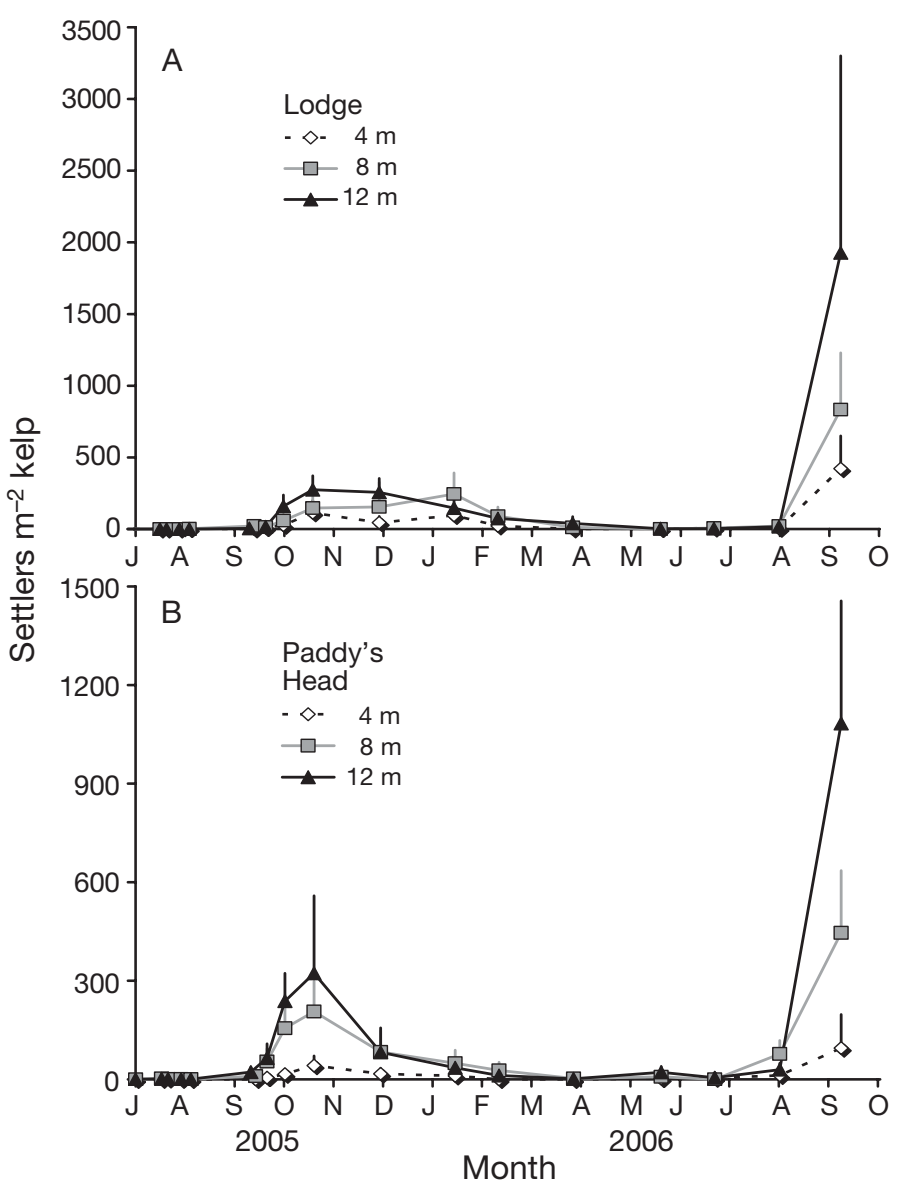

Fig. 6. Membranipora membranacea settlers on Laminaria longicruris. Abundance (mean $+\mathrm{SD}, \mathrm{n}=7$ to 15 ) at 3 depths, at (A) Lodge and (B) Paddy's Head within St. Margarets Bay, Nova Scotia, from 1 July 2005 to 14 September 2006 declined until April. In 2006, the lowest abundances were observed from March to May (0 to $2.6 \pm 4.8$ ind. $\mathrm{m}^{-2}$ kelp). Abundance increased from May through to September 2006 at both sites. The highest abundances for the study period were observed in September 2006, at $12 \mathrm{~m}$ depth at both sites (Paddy's Head, $12 \mathrm{~m}: 1083 \pm$ 372 ind. $\mathrm{m}^{-2}$ kelp, $\mathrm{n}=8$; Lodge, $12 \mathrm{~m}$ : $1926 \pm 1373$ ind. $\mathrm{m}^{-2}$ kelp, $\mathrm{n}=8$ ).

Temporal settlement patterns were similar between sites in summer and early autumn, but differed in late autumn and winter (Fig. 6). At Paddy's Head, settler abundance decreased after 19 October 2005, whereas, at Lodge, abundance remained high until January 2006 and subsequently declined. Water temperatures from December to April were $<5^{\circ} \mathrm{C}$ (Fig. 2); it is not known whether settlers develop into colonies at those temperatures, and, if so, at what rate. It is possible that settlers observed in winter had settled many weeks or months previously.

There was considerable inter-annual variability in the timing of occurrence and in the abundance of settlers (Fig. 7). Overall, the settlement season was advanced in 2006 compared to 2005. Seasonal increases in settlers were first observed in July in 2005, and in May in 2006. Pronounced increases in the abundance of settlers were first observed in September in 2005, and in August in 2006 (Figs. 6 \& 7). Furthermore, abundance in September 2006 was 2 orders of magnitude greater than in September 2005, and 1 order of magnitude greater than during the peak of settlement (19 October) in 2005 (Figs. 6 \& 7).

The bathymetric patterns in abundance of settlers were similar for the 4 dates tested (Fig. 6, Table 2). In August 2006, at both sites, abundance of settlers was farther towards the mouth of the bay, so cross-shelf directional motions in the water column (e.g. up- and downwelling) reach Lodge slightly later than Paddy's Head.

\section{Settler patterns}

The abundance of settlers was strongly seasonal (Fig. 6). In 2005, the first new settlers were observed at both sites in early July, and were present in low abundance ( 0 to $2.7 \pm 4.3$ ind. $\mathrm{m}^{-2}$ kelp, mean \pm SD) through July and August. The abundance of settlers increased in September, peaked on 19 October 2005 (Paddy's Head, 12 m: $323 \pm 235$ ind. $\mathrm{m}^{-2}$ kelp, $\mathrm{n}=9$; Lodge, $12 \mathrm{~m}: 275 \pm 97$ ind. $\mathrm{m}^{-2}$ kelp, $\mathrm{n}=10$ ) and

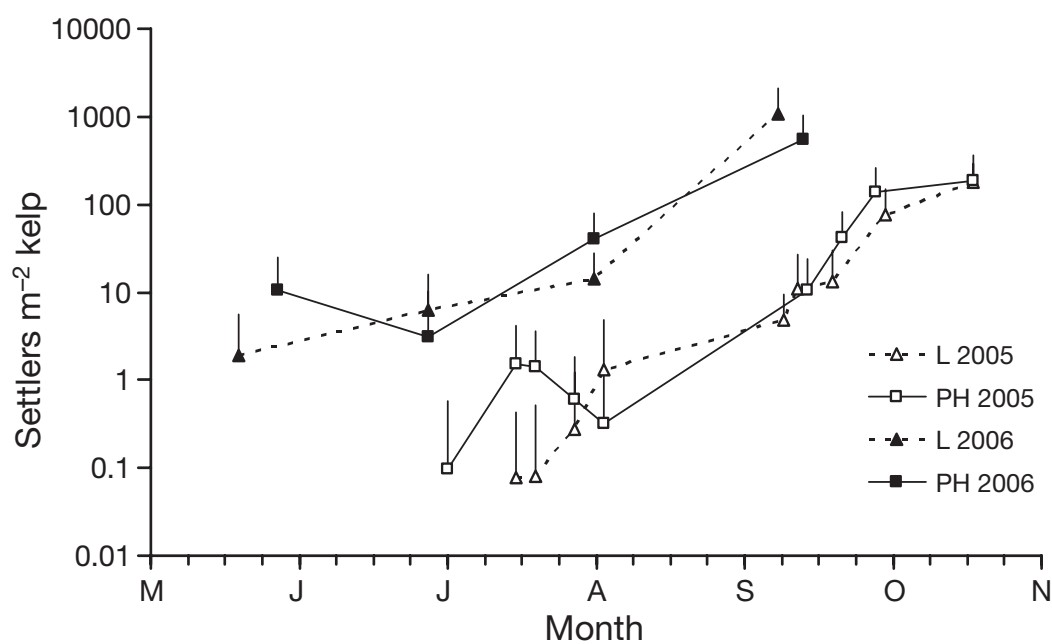

Fig. 7. Membranipora membranacea settlers on individual Laminaria longicruris blades. Abundance (mean $+\mathrm{SD}, \mathrm{n}=24$ to 43 ) at Lodge (L) and Paddy's Head $(\mathrm{PH})$ in St. Margarets Bay, Nova Scotia, pooled across 3 depths, from 1 July to 19 October 2005 and from 21 May to 14 September 2006 
Table 2. ANOVA on the effects of depth and site on the abundance of settlers of Membranipora membranacea done for the dates of maximum settlement in 2005 (September and October) and 2006 (August and September). L: Lodge; PH: Paddy's Head

\begin{tabular}{|c|c|c|c|c|}
\hline Effect & MS & $F_{(\mathrm{df})}$ & $\mathrm{p}$ & Tukey's HSD \\
\hline \multicolumn{5}{|l|}{ Sep 2005} \\
\hline Site & 0.16 & $0.97_{(1,47)}$ & 0.33 & 4, 8, $12 \mathrm{~m}: \mathrm{PH}=\mathrm{L}$ \\
\hline Depth & 5.97 & $36 \cdot 3_{(2,47)}$ & $<0.0001$ & $\mathbf{L}: 4 \mathrm{~m}=8 \mathrm{~m}=12 \mathrm{~m}$ \\
\hline Depth $\times$ Site & 0.56 & $3.43_{(2,47)}$ & 0.04 & PH: $4 \mathrm{~m}<8 \mathrm{~m}=12 \mathrm{~m}$ \\
\hline Error & 0.16 & & & \\
\hline \multicolumn{5}{|l|}{ Oct 2005} \\
\hline Site & 1.29 & $0.08_{(1,57)}$ & 0.78 & 4, 8, $12 \mathrm{~m}: \mathrm{PH}=\mathrm{L}$ \\
\hline Depth & 19.6 & $11 \cdot 6_{(2,57)}$ & $<0.0001$ & $\mathrm{~L}: 4 \mathrm{~m}=8 \mathrm{~m}=12 \mathrm{~m}$ \\
\hline Depth $\times$ Site & 3.12 & $4 \cdot 16_{(2,57)}$ & 0.02 & PH: $4 \mathrm{~m}<8 \mathrm{~m}=12 \mathrm{~m}$ \\
\hline Error & 0.68 & & & \\
\hline \multicolumn{5}{|l|}{ Aug 2006} \\
\hline Site & 2.24 & $8.83_{(1,53)}$ & 0.005 & $\mathrm{~L}<\mathrm{PH}$ \\
\hline Depth & 3.50 & $13 \cdot 8_{(2,53)}$ & $<0.0001$ & $4 \mathrm{~m}<8 \mathrm{~m}=12 \mathrm{~m}$ \\
\hline Depth $\times$ Site & 0.08 & $0.32_{(2,53)}$ & 0.72 & \\
\hline Error & 0.16 & & & \\
\hline \multicolumn{5}{|l|}{ Sep 2006} \\
\hline Site & 3.07 & $15.4_{(1,42)}$ & 0.0003 & $4 \mathrm{~m}: \mathrm{PH}<\mathrm{L}$ \\
\hline Depth & 4.82 & $24.3_{(2,42)}$ & $<0.0001$ & 8, $12 \mathrm{~m}: \mathrm{PH}=\mathrm{L}$ \\
\hline Depth $\times$ Site & 1.01 & $5.07_{(2,42)}$ & 0.01 & PH: $4 \mathrm{~m}<8 \mathrm{~m}=12 \mathrm{~m}$ \\
\hline Error & 0.20 & & & $\mathbf{L}: 4 \mathrm{~m}=8 \mathrm{~m}=12 \mathrm{~m}$ \\
\hline
\end{tabular}

lower at 4 than at 8 and $12 \mathrm{~m}$. For the other 3 dates, abundance was lower at 4 than at 8 and $12 \mathrm{~m}$ at Paddy's Head, but did not vary significantly across depths at Lodge. Comparison between sites showed that abundance of settlers was similar between the 2 sites for all dates and depths, except for August 2006 (when abundance was greater at Paddy's Head than at Lodge) and September 2006 (when abundance was greater at Lodge than at Paddy's Head, but only at $4 \mathrm{~m}$ ).

\section{Relationships between temperature and settlement}

We obtained consistently strong relationships between abundance of settlers and the temperature regime (Table 3). GDD was always included in the stepwise multiple linear regressions, whereas $T$ was only included at $12 \mathrm{~m}$, and the effects of $\Delta T$ and $T^{\prime}$ were inconsistent. For all significant relationships, settlers were positively related to GDD and $T$, and negatively related to $\Delta T$ and $T^{\prime}$. When data from both sites and all depths were combined, GDD and $\Delta T$ explained $65 \%$ of the variance in settler abundance (Table 3). At Lodge, GDD and $\Delta T$ explained $76 \%$ of the variance in abundance, whereas at Paddy's Head, GDD explained $54 \%$ of the variance in abundance. At $8 \mathrm{~m}, \mathrm{GDD}$ explained $69 \%$ of the variance in abundance, whereas at $12 \mathrm{~m}, \mathrm{GDD}$ and $T^{\prime}$ explained $63 \%$ of the variance in abundance.

Because GDD was the variable most consistently included in the multiple regressions explaining settler abundance, and because settler abundance was an order of magnitude higher in 2006 than in 2005, we examined the direct relationship between GDD and settlers, for both years and for each year independently, using simple linear regressions. When data from both years were included in the analysis, GDD explained $62 \%$ of the variance in settler abundance $\left(F_{(1,76)}=128, \mathrm{p}<0.001\right)$. When the years were considered separately, GDD explained 76 to $81 \%$ (2005: $F_{(1,52)}=226, \mathrm{p}<0.001, \mathrm{r}^{2}=0.81$; 2006: $\left.F_{(1,22)}=72.8, \mathrm{p}<0.001, \mathrm{r}^{2}=0.76\right)$ of the variance in settler abundance (Fig. 8). The slopes of the regressions did not vary between years $\left(t_{(1,75)}=-0.78, \mathrm{p}>0.05\right)$, although the elevation was greater in 2006 than in 2005 (ANCOVA, $\left.F_{(1,75)}=75.5, \mathrm{p}<0.001\right)$.

\section{DISCUSSION}

GDD, a measure of thermal history, explained up to $81 \%$ of the variability in the abundance of settlers of the introduced bryozoan Membranipora membranacea in St. Margarets Bay, Nova Scotia. The strong relationship between GDD and the abundance of M. membranacea settlers suggests that predicted increases in temperature attributable to anthropogenically induced climate change (IPCC 2001) may cause increases in abundance of this introduced species. GDD has been used to model climate change effects in many agricultural and forestry systems (e.g. De Melo-Abreu et al. 2004), but it has been used infrequently for studies of marine systems (Neuheimer \& Taggart 2007). The rela-

Table 3. Results of multiple linear regression analyses exploring relationships between the abundance of settlers of Membranipora membranacea $[\log (x+1)$ transformed] and indices of temperature regime for different site and depth combinations. See 'Materials and methods' for calculations for growing degreeday (GDD), weekly temperature $(T)$, stratification $(\Delta T)$, and temperature fluctuations $\left(T^{\prime}\right) . \mathrm{p}<0.001$ for all tests

\begin{tabular}{|llcc|}
\hline Location & Eq. for log(settlers + 1) & $\mathrm{r}^{2}$ & $F_{(\mathrm{df})}$ \\
\hline All locations (all data) & $=0.001 \mathrm{GDD}-0.121 \Delta T-0.336$ & 0.653 & $67.8_{(2,69)}$ \\
Lodge (all depths) & $=0.001 \mathrm{GDD}-0.141 \Delta T-0.282$ & 0.762 & $57.0_{(2,33)}$ \\
Paddy's Head (all depths) & $=0.001 \mathrm{GDD}-0.901$ & 0.538 & $41.8_{(1,34)}$ \\
$4 \mathrm{~m}$ (both sites) & $=0.001 \mathrm{GDD}-0.462 T^{\prime}-0.004$ & 0.630 & $20.6_{(2,21)}$ \\
$8 \mathrm{~m}$ (both sites) & $=0.001 \mathrm{GDD}-1.202$ & 0.686 & $51.2_{(1,22)}$ \\
$12 \mathrm{~m}$ (both sites) & $=0.001 \mathrm{GDD}+0.125 T-1.301$ & 0.697 & $27.5_{(2,21)}$ \\
\hline
\end{tabular}




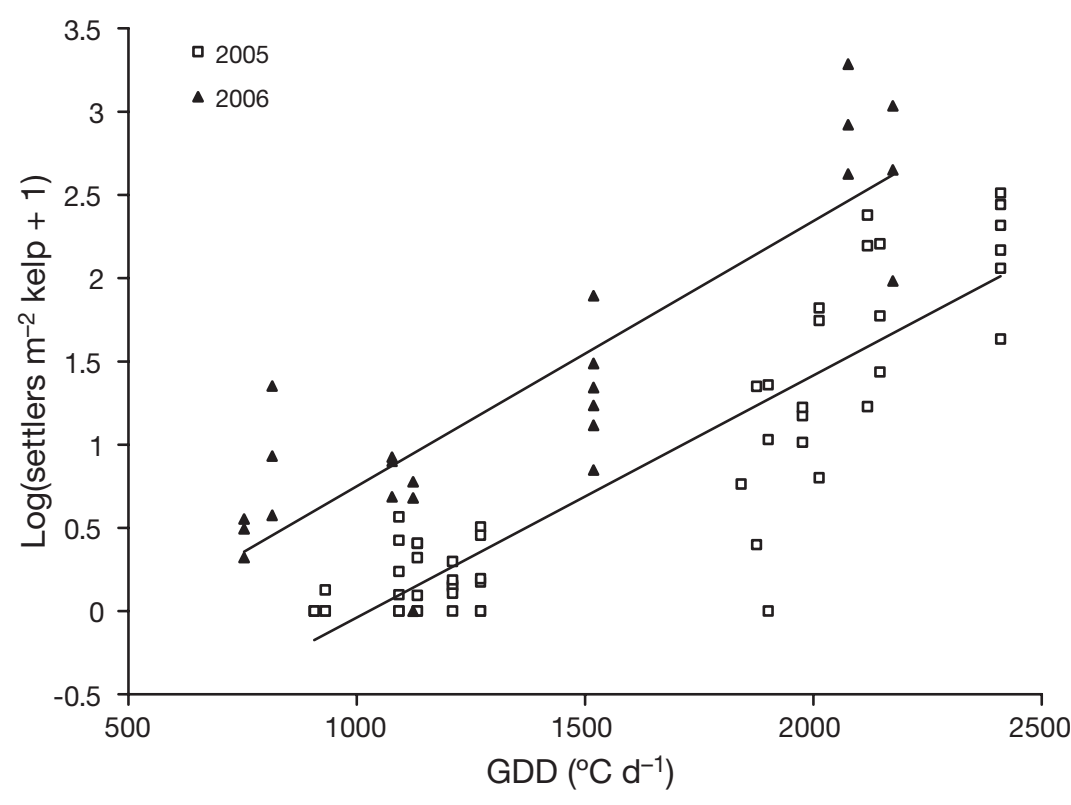

Fig. 8. Membranipora membranacea. Relationships between the abundance of settlers and growing degree-day (GDD) from 1 July to 19 October 2005 and from 21 May to 14 September 2006, for all depths and both sites, combined, in $2005\left(R^{2}=0.81\right)$ and $2006\left(R^{2}=0.76\right)$

tionship between increased temperatures associated with climate change and species invasions has also not been as thoroughly addressed in marine as in terrestrial systems (Carlton 2000, Stachowicz et al. 2002). In one of few studies, invasive tunicates settled earlier in the season than native tunicates during years with warmer winters in New England (Stachowicz et al. 2002). In the Wadden Sea, recruitment of invasive oysters was higher in years with above-average summer sea surface temperature (Diederich et al. 2005). The importance of changes in extreme temperatures (such as winter or summer temperatures) for invertebrate population dynamics is well known for insects (Sinclair et al. 2003). For example, increased temperatures can result in increased insect (many of which are introduced or pest species) populations (e.g. Battisti et al. 2006). Our results suggest that populations of marine bryozoans, like many other invertebrates, are sensitive to changes in winter temperature. For an invasive species such as $M$. membranacea, which suffers little predation or competition in its introduced habitat (Berman et al. 1992), warmer winter temperatures may result in dramatic increases in population size.

Within each year, abundance of settlers increased exponentially from onset until the peak of settlement. Because GDD is related approximately linearly to time, it is possible that the observed relationship between abundance of settlers and GDD reflects this increase over the growing season. However, by standardising settlement rate to GDD rather than to time, we can generalise comparisons between years, as well as among regions with different thermal regimes (e.g. northern vs. southern hemisphere; sub-polar vs. temperate environment). The effect of thermal history on settlement was consistent between years, as indicated by the lack of a difference in slopes between years. However, the elevation of the regression was higher for 2006 than for 2005. If GDD alone was responsible for explaining the variability in abundance of settlers, then the elevations of the regressions would not differ significantly between years. We suggest that warmer winter temperatures allow a greater number of adult colonies to overwinter, bud new growth, become reproductive, and provide larvae for the next season. Early season settlers can then grow into reproductively active adults, and produce larvae later in the same season. We propose that it is this increase in adult colonies and consequent increase in settlers that is reflected in increased elevation. In winter 2006, many of the observed overwintering colonies continued to grow, as indicated by a 'milky fringe' at the edge of the colony (Lutaud 1961). Furthermore, settlers were observed on all sampling dates throughout the winter of 2006. In contrast, in the winter of 2005, colonies were fragmented and covered in algae and detritus, and regenerated growth (Menon 1972) was not observed until June 2005. The absence of new juveniles or adults in the spring of 2005 (M. Saunders unpubl. data) suggests that settlement was not occurring at that time.

There was a weak, negative relationship between stratification and abundance of settlers at Lodge, but not at Paddy's Head, perhaps because of greater surface mixing due to waves at the more exposed location. While other studies (Yoshioka 1973, Bernstein \& Jung 1979, Scrope-Howe \& Jones 1986) have attributed seasonal bathymetric patterns in larvae or settlers to stratification, our results were equivocal. We observed lower settlement at $4 \mathrm{~m}$ than at 8 and $12 \mathrm{~m}$, both in the presence and in the absence of stratification. Significant differences in settler abundance across depths were observed on 19 October 2005 and in early September 2006, when the water column had been wellmixed for over $1 \mathrm{wk}$. Although stratification probably has an effect on bathymetric patterns of settler abundance, variables other than temperature can also influence larval abundance in the water column. Many other abiotic (light, salinity, density structure) and 
biotic (predators, prey) variables that vary across bathymetric gradients can also influence zooplankton distributions (Scrope-Howe \& Jones 1986).

Fluctuations in temperature were less important than stratification in explaining abundance of settlers. Peak abundances in both years occurred when water temperatures had been stable $\left(T^{\prime}<0.7^{\circ} \mathrm{C}\right)$ for periods $>1$ wk. However, early (May 2006) and late (September 2005) seasonal increases in the abundance of settlers occurred when water temperature was fluctuating widely due to wind-driven upwelling. It is possible that changes in abundance of settlers coincided with sharp changes in temperature caused by cross-shelf directional movements in the water column (e.g. upwelling or downwelling). Such mechanisms of larval transport have been previously suggested. In California, cyphonautes were more abundant on the shoreward, colder side of fronts than on the warmer, offshore side (Pineda 1999). Conversely, Yoshioka (1973) hypothesised that upwelling of cold, nutrient-rich, larval-deficient deep water, pushed larval-rich surface water offshore, resulting in a decrease in larval abundance and settlement. On the east coast of North America, the effect of oceanographic features on larval supply of Membranipora membranacea has not been investigated, although the importance of wind- and buoyancy-driven flow for larval transport of other invertebrates and fish is recognised (Epifanio \& Garvine 2001).

The strong relationship between the temperature regime and the abundance of settlers may not necessarily be causative, because a number of factors can co-vary with temperature. For example, increased temperatures may be a result of decreased exchange between the bay and the open ocean, resulting in increased larval retention, and thus increased local settlement. Similarly, abundance of phytoplankton is related to temperature, and may have affected growth rate of adult colonies (O'Dea \& Okamura 1999) and resulted in increased larval production. Abundance of Membranipora membranacea in Nova Scotia has fluctuated widely since its introduction in the early 1990s (R. E. Scheibling unpubl. data), suggesting that increases in abundance in 2006 were not simply due to expansion of this introduced population.

The seasonal patterns in the abundance of settlers of Membranipora membranacea in Nova Scotia differ from those of larval supply (larvae or settlers) reported for other regions. In Lough Hyne, Ireland, highest abundances were observed in May and August (Greenwood et al. 2001). On the Isle of Man, cyphonautes occurred in plankton samples from February to November, and settlers were abundant from June to August (Eggleston 1972). In Southern California, larval and new settler abundance on the kelp Macrocystis pyrifera peaked in late winter and was lowest in late summer (Bernstein \& Jung 1979, Yoshioka 1982). At Friday Harbor, Washington, settlement occurred from May until September (Harvell et al. 1990). Between 45 and $55^{\circ} \mathrm{N}$, there appears to be a trend towards later seasonal settlement in locations with colder winter temperatures (e.g. spring and summer in Washington and Ireland and autumn in Nova Scotia). Across latitudinal scales, larvae and settlers occur in spring, summer, or early autumn in northern regions (e.g. Washington and Ireland) and in winter in southern regions (Southern California). Similar latitudinal trends in seasonality have been observed for other species, including molluscs and annelids (Lewis 1986), and may be attributed to shorter growing seasons in northern regions, compared to summer heat stress in southern regions (Lewis 1986).

We have documented spatial and temporal patterns in settler abundance of the introduced bryozoan Membranipora membranacea in Nova Scotia, and demonstrated that GDD, a measure of thermal history, explains most of the variance in settler abundance. Settlement is considered a critical stage in the life history of benthic invertebrates, and has important consequences in population dynamics. For an introduced invertebrate, such as $M$. membranacea, increases in settlement may have important ecological effects. At Friday Harbor, M. membranacea larvae that settled earlier in the season lived longer (Harvell et al. 1990). Furthermore, growth rate is positively related to temperature (Lutaud 1961, Menon 1972) and size, so warm temperatures may allow colonies to reach larger sizes. Our results suggest a possible synergism between increased temperatures caused by climate change and introduced invasive marine species. This may have a considerable effect on kelp beds in Atlantic North America, where colonies can reach sufficient sizes to defoliate kelp beds during fall storms (Scheibling et al. 1999). To further understand the mechanisms regulating settlement and, thus, the population dynamics of this species, the relationship between large-scale oceanographic events and larval supply of $M$. membranacea in its native and introduced regions clearly merits further investigation.

Acknowledgements. We thank J. Lindley, A. Pinder, J. S. Lauzon-Guay, D. Lyons, D. Taylor, J. Sperl and B. Rowland, and many others, for their assistance with the underwater work, and M. Beck and D. Knip for their assistance in the laboratory. Dr. R. E. Scheibling provided comments on an earlier draft of this manuscript. This research was funded by Natural Sciences and Engineering Research Council of Canada (NSERC) Discovery Grants to A.M. and R. E. Scheibling, and an NSERC Canada Graduate Scholarship and Dalhousie University Graduate Scholarship to M.S. 


\section{LITERATURE CITED}

Atkinson D (1994) Temperature and organism size-a biological law for ectotherms? Adv Ecol Res 25:1-58

Battisti A, Stastny M, Buffo E, Larsson S (2006) A rapid altitudinal range expansion in the pine processionary moth produced by the 2003 climatic anomaly. Global Change Biol 12(4):662-671

Berman J, Harris L, Lambert W, Buttrick M, Dufresne M (1992) Recent invasions of the Gulf of Maine: three contrasting ecological histories. Conserv Biol 6(3):435-441

Bernstein BB, Jung N (1979) Selective pressures and coevolution in a kelp canopy community in southern California. Ecol Monogr 49(3):335-355

Caley MJ, Carr MH, Hixon MA, Hughes TP, Jones GP, Menge BA (1996) Recruitment and the local dynamics of open marine populations. Annu Rev Ecol Syst 27: $477-500$

Canadian Tide and Current Tables (1988) Atlantic coast and Bay of Fundy, Vol 1. Dept Fish Oceans, Ottawa

Carlton JT (1989) Man's role in changing the face of the ocean: biological invasions and implications for conservation of near-shore environments. Conserv Biol 4: $265-273$

Carlton JT (2000) Global change and biological invasions in the oceans. In: Mooney HA, Hobbs RJ (eds) Invasive species in a changing world. Island Press, Washington, DC, p 31-54

Chapman AS, Scheibling RE, Chapman ARO (2002) Species introductions and changes in the marine vegetation of Atlantic Canada. In: Claudi R, Nantel P, Muckle-Jeffs E (eds) Alien invaders in Canada's waters, wetlands, and forests. Natural Resources Canada, Canadian Forest Service, Science Branch, Ottawa, p 133-148

De Melo-Abreu JP, Barranco D, Cordeiro AM, Tous J, Rogado B, Villalobos F (2004) Modeling olive flowering date using chilling for dormancy release and thermal time. Agric For Meteorol 125(1-2):117-127

Diederich S, Nehls G, van Beusekom JEE, Reise K (2005) Introduced Pacific oysters (Crassostrea gigas) in the northern Wadden Sea: invasion accelerated by warm summers? Helgol Mar Res 59(2):97-106

Dixon J, Shroeter SC, Kastendiek J (1981) Effects of the encrusting bryozoan Membranipora membranacea on the loss of blades and fronds by the giant kelp Macrocystis pyrifera (Laminariales). J Phycol 17:341-345

Eggleston D (1972) Patterns of reproduction in the marine Ectoprocta of the Isle of Man. J Nat Hist 6:31-38

Ellison AM, Harvell CD (1989) Size hierarchies in Membranipora membranacea: Do colonial animals follow the same rules as plants? Oikos 55:349-355

Epifanio CE, Garvine RW (2001) Larval transport on the Atlantic continental shelf of North America: a review. Estuar Coast Shelf Sci 52(1):51-77

Gerard VA, Mann KH (1979) Growth and production of Laminaria longicruris (Phaeophyta) populations exposed to different intensities of water movement. J Phycol 15: $33-41$

Greenwood A, O'Riordan RM, Barnes DKA (2001) Seasonality and vertical zonation of zooplankton in a semi-enclosed sea lough. J Mar Biol Assoc UK 81:213-220

Grosholz ED (1996) Contrasting rates of spread for introduced species in terrestrial and marine systems. Ecology 77(6): 1680-1686

Harvell CD, Caswell H, Simpson P (1990) Density effects in a colonial monoculture: experimental studies with a marine bryozoan (Membranipora membranacea L.). Oecologia 82:227-237

Heath RA (1973) Flushing of coastal embayments by changes in atmospheric conditions. Limnol Oceanogr 18(6): 849-862

IPCC (2001) Third assessment report: climate change 2001. Intergovernmental Panel on Climate Change, Geneva

Lambert WJ, Levin PS, Berman J (1992) Changes in the structure of a New England (USA) kelp bed: the effects of an introduced species? Mar Ecol Prog Ser 88:303-307

Lane CE, Mayes C, Druehl LD, Saunders GW (2006) A multigene molecular investigation of the kelp (Laminariales, Phaeophyceae) supports substantial taxonomic re-organization. J Phycol 42:493-512

Levin PS, Coyer JA, Petrik R, Good TP (2002) Communitywide effects of nonindigenous species on temperate rocky reefs. Ecology 83(11):3182-3193

Lewis JR (1986) Latitudinal trends in reproduction, recruitment and population characteristics of some rocky littoral molluscs and cirripedes. Hydrobiologia 142:1-13

Lutaud G (1961) Contribution à l'étude du bourgeonnement et de la croissance des colonies chez Membranipora membranacea bryozoaire cheilostome. Ann Soc R Zool Belg 91: 157-199

Menon NR (1972) Heat tolerance, growth and regeneration in three North Sea bryozoans exposed to different constant temperatures. Mar Biol 15:1-11

Neuheimer AB, Taggart CT (2007) The growing degree-day and fish size-at-age: the overlooked metric. Can J Fish Aquat Sci 64:375-385

O'Dea A, Okamura B (1999) Influence of seasonal variation in temperature, salinity and food availability on module size and colony growth of the estuarine bryozoan Conopeum seurati. Mar Biol 135:581-588

Petrie B, Topliss BJ, Wright DG (1987) Coastal upwelling and eddy development off Nova Scotia. J Geophys Res C 29(12):12979-12991

Pineda J (1999) Circulation and larval distribution in internal tidal bore warm fronts. Limnol Oceanogr 44(6):1400-1414

Pineda J (2000) Linking larval settlement to larval transport: assumptions, potentials, and pitfalls. Oceanogr East Pac 1: $61-81$

Ricciardi A, Rasmussen JB (1998) Predicting the identity and impact of future biological invaders: a priority for aquatic resource management. Can J Fish Aquat Sci 55(7): $1759-1765$

Scheibling RE, Hennigar AW, Balch T (1999) Destructive grazing, epiphytism, and disease: the dynamics of sea urchin-kelp interactions in Nova Scotia. Can Bull Fish Aquat Sci 56:2300-2314

Schwaninger HR (1999) Population structure of the widely dispersing marine bryozoan Membranipora membranacea (Cheilostomata): implications for population history, biogeography, and taxonomy. Mar Biol 135:411-423

Scrope-Howe S, Jones DA (1986) The vertical distribution of zooplankton in the western Irish Sea. Estuar Coast Shelf Sci 22(6):785-802

Seed R, O'Connor RJ (1981) Community organization in marine algal epifaunas. Annu Rev Ecol Syst 12:49-74

Sinclair BJ, Vernon P, Klok CJ, Chown SL (2003) Insects at low temperatures: an ecological perspective. Trends Ecol Evol 18(5):257-262

Stachowicz JJ, Terwin JR, Whitlatch RB, Osman RW (2002) Linking climate change and biological invasions: ocean warming facilitates nonindigenous species invasions. Proc Natl Acad Sci USA 99(24):15497-15500

Thresher R, Proctor C, Ruiz G, Gurney T, MacKinnon C, Wal- 
ton W, Rodriguez L, Bax N (2003) Invasion dynamics of the European shore crab, Carcinus maenas, in Australia. Mar Biol 142:867-876

Trudgill DL, Honek A, Li D, van Straalen NM (2005) Thermal time-concepts and utility. Ann Appl Biol 146(1):1-14 Yoshioka PM (1973) The population dynamics and ecology of

Editorial responsibility: Otto Kinne (Editor-in-Chief), Oldendorf/Luhe, Germany the encrusting ectoproct Membranipora serrilamella. Dissertation, Scripps Institute of Oceanography, University of California San Diego, p 143 + xii

Yoshioka PM (1982) Role of planktonic and benthic factors in the population dynamics of the bryozoan Membranipora membranacea. Ecology 63(2):457-468

Submitted: November 8, 2006; Accepted: February 16, 2007 Proofs received from author(s): August 9, 2007 